\title{
MEKANISME PASAR ISLAMI
}

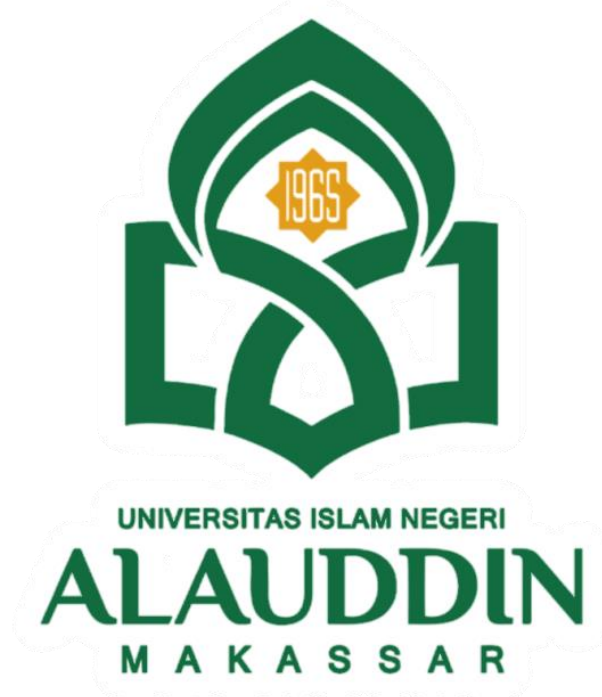

DISUSUN OLEH KELOMPOK 11:

- MUHAMMAD RIFALDI 90500120080

- $\quad$ ANDI MARHUNI T 90500120083

- $\quad$ NABILA RAJAB 90500120086

DOSEN PENGAMPU : SAMSUL, S.A.B., MA.

\author{
JURUSAN PERBANKAN SYARIAH \\ FAKULTAS EKONOMI DAN BISNIS ISLAM \\ UNIVERSITAS ISLAM NEGERI ALAUDDIN MAKASSAR
}

TAHUN AJARAN 2021/2022 


\section{KATA PENGANTAR}

Puji syukur kehadirat Allah SWT yang telah memberikan rahmat dan hidayah-Nya sehingga saya dapat menyelesaikan tugas makalah yang berjudul MEKANISME PASAR ISLAM ini tepat pada waktunya.

Adapun tujuan dari penulisan dari makalah ini adalah untuk memenuhi tugas akhir pada mata kuliah Ekonomi Mikro Perbankan Syariah. Selain itu, makalah ini juga bertujuan untuk menambah wawasan tentang MEKANISME PASAR ISLAM bagi para pembaca dan juga bagi penulis.

Kami mengucapkan terima kasih kepada Bapak Samsul, S.A.B., AM.selaku dosen mata kuliah Ekonomi Mikro Perbankan Syariah yang telah memberikan tugas ini sehingga dapat menambah pengetahuan dan wawasan sesuai dengan bidang studi yang kami tekuni.

Kami juga mengucapkan terima kasih kepada semua pihak yang telah membagi sebagian pengetahuannya sehingga kami dapat menyelesaikan makalah ini.

Kami menyadari, makalah yang saya tulis ini masih jauh dari kata sempurna. Oleh karena itu, kritik dan saran yang membangun akan saya nantikan demi kesempurnaan makalah ini.

Gowa, 28 November 2021

PENULIS 


\section{DAFTAR ISI}

11 BATA PENGANTAR




\section{BAB I \\ PENDAHULUAN}

\section{A. LATAR BELAKANG}

Pasar adalah tempat bertemunya antara penjual dan pembeli dan melakukan transaksi barang atau jasa. Pasar merupakan sebuah mekanisme pertukaran barang dan jasa yang alamiah dan telah berlangsung sejak awal peradaban manusia. Dalam Islam pasar sangatlah penting dalam perekonomian. Pasar telah terjadi pada masa Rasulullah dan Khulafaur Rasyidin dan menjadi sunatullah yang telah di jalani selama berabad-abad(P3EI, 2011).

Islam adalah agama yang sempurna. Hal ini dikarenakan didalamnya dibahas nilai-nilai, etika, dan pedoman hidup secara komperhensif. Islam pula merupakan agama penyempurna agama-agama terdahulu dan mengatur seluruh aspek kehidupan manusia baik persoalan aqidah maupun muamalah. Dalam hal muamalah, Islam mengatur kaitannya dengan relasi manusia dengan sesama dalam rangka memenuhi kebutuhan hidupnya sehari-hari termasuk didalamnya dituntun bagaimana cara pengelolaan pasar dan segala bentuk mekanismenya.

Peranan ekonomi Islam dalam mekanisme pasar menyumbangkan andil yang amat penting di tengah carut-marut kondisi perekonomian bangsa Indonesia. Praktek pasar sejatinya harus ditampilkan nilai-nilai yang sesuai dengan norma dan nilai yang dibenarkan. Dua paham ekonomi yang selama ini menjadi acuan dan barometer dunia, 
yaitu ekonomi kapitalis dan ekonomi sosialis ternyata tidak dapat mengatur mekanisme kegiatan pasar saat ini yang serba tidak menentu dan tidak jelas, malah semakin memperparah keadaan (Wiharto, 2008). ${ }^{1}$

\section{B. RUMUSAN MASALAH}

1. Mengidentifikasi pasar di Masa Rasulullah

2. Mengidentifikasi pandangan Ekonom Muslim

3. Mengidentifikasi peranan pemerintah dalam mengawasi pasar

\section{TUJUAN}

Adapun tujuan dari penulisan dari makalah ini adalah untuk memenuhi tugas akhir pada mata kuliah Ekonomi Mikro Perbankan Syariah. Selain itu, makalah ini juga bertujuan untuk menambah wawasan tentang MEKANISME PASAR ISLAM bagi para pembaca dan juga bagi penulis.

Rahmi Ain.(2015). Mekanisme Pasar dalam Islam. Jurnal Ekonomi Bisnis dan Kewirausahaan.4(2): 177

Rahmi Ain.(2015). Mekanisme Pasar dalam Islam. Jurnal Ekonomi Bisnis dan Kewirausahaan.4(2): 178 


\section{BAB II \\ PEMBAHASAN}

\section{A.MEKANISME PASAR DI MASA RASULULLAH}

Pasar berperan sangat penting dalam perekonomian masyarakat muslim pada masa Rasulullah SAW dan Khulafaur Rasyidin. Bahkan, Rasulullah SAW sendiri pada awalnya adalah seorang pebisnis, demikian pula Khulafaur Rasyidin dan kebanyakan sahabat. Pada usia tujuh tahun, Muhammad telah diajak oleh pamannya Abu Thalib melakukan perjalanan perdagangan ke negeri Syam. Dari sinilah ilmu perniagaan beliau diasah.

Kemudian, sejalan dengan usianya semakin dewasa, Muhammad semakin giat berdagang, baik dengan modal sendiri, ataupun bermitra dengan orang lain. Kemitraan dengan skema mudharabah dan musyarakah dapat dianggap cukup populer pada masyarakat Arab pada waktu itu. Salah Satu mitra bisnisnya adalah Khadijah seorang wanita pengusaha yang cukup disegani di Makkah, yang akhirnya menjadi istri beliau. Berkali-kali Muhammad terlibat urusan dagang ke luar negeri (Syam, Suriah, Yaman dan lain-lain) dengan membawa modal dari Khadijah. Setelah menjadi suami Khadijah pun, Muhammad juga tetap aktif berbisnis, termasuk berdagang di pasar lokal sekitar kota Makkah.

${ }^{2}$ Nabi Muhammad SAW. seorang pedagang profesional dan selalu menjungjung tingi kejujuran. Beliau mendapat julukan al-amin (yang terpercaya). Setelah menjadi Rasul, Nabi Muhammad SAW. memng tidak lagi menjadi pelaku bisnis secara aktif karena situasi dan kondisi yang tidak memungkinkan. Pada saat awal perkembangan Islam di Mekkah, Rasulullah SAW. dan masyarakat Muslim mendapat gangguan dan teror yang

Ghafur Abd. (2019) . Mekanisme Pasar Perspektif Islam.Jurn Iqtishodiyah.5(1) (6-7) 
berat dari masyarakat kafir Mekkah (terumatam suku Quraisy, suku Rasulullah SAW. sendiri) sehingga perjuangan dan dakwah merupakan prioritas. Ketika masyarakat Muslim telah berhijrah ke Madinah, peranan Rasulullah SAW. bergeser menjadi pengawas pasar atau al-Muhtasib. Beliau mengawasi jalannya mekanisme pasar di Madinah agar tetap berlangsung secara Islam.

Pada sasat itu mekanisme pasar sangat dihargai. Rasulullah SAW. menolak untuk membuat kebijakan penetepan harga manakala tingkat harga di Madinah tiba-tiba naik. Selama kenaikan terjadi karena kekuatan permintaan dan penawaran yang murni, yang tidak disertai dengan dorongan monopolistik dan monospolistik, tidak ada alasan bagi Rasulullah SAW. untuk tidak menghormati harga pasar. Pada saat itu para sahabat berkata,

"Wahai Rasulullah, tentukan harga untuk kita! Beliau menjawab, Allah itu sesunguhnya penentu harga, penahan, pencurah, serta pemberi rezeki. Aku berharap dapat menemui Tuhanku di mana salah seorang kalian tidak menuntutku karena ke zaliman dalam hal darah dan harta."

Dalam hadis tersebut jelas bahwa pasar merupakan hukum alam (sunnatullah) yang harus dijunjung tinggi. Tidak seorangpun secara individual dapat memengaruhi pasar sebab pasar adalah kekuatan kolektif yang telah menjadi ketentuan Allah SWT.

Ghafur Abd. (2019) . Mekanisme Pasar Perspektif Islam.Jurn Iqtishodiyah.5(1) (6-7) 


\section{B.PANDANG EKONOM MUSLIM}

Pasar telah mendapatkan perhatian cukup memadai dari para ulama klsik, seprti Abu Yusuf, al-Ghazali, Ibnu Khaldun, dan Ibnu Taimiyah. Pemikiran-pemikiran mereka tentang pasar tidak hanya mampu memberikan analisis yang tajam tentang apa yang terjadi pada masa itu.

\section{Mekanisme Pasar menurut Abu Yusuf (731-798 M)}

Pemikiran Abu Yusuf tentang pasar dapat dijumpai dalam bukunya al-Kharaj. Selain membahas prinsip perpajakan dan anggaran negara yang menjadi pedoman kekhalifahan Harun Ar-Rasyid di Baghdad, buku. Tulisan pertamanya menguraikan naik dan turunnya produksi yang dapat memengaruhi harta.

Masyarakat luas pada masa itu memahami bahwa harga suatu barang hanya ditentukan oleh jumlah penawarannya. Dengan kata lain, apabila hanya tersedia sedikit barang, harga akan mahal. Sebaliknya, jika tersedia barang banyak harga akan murah. Mengenai hal ini Abu Yusuf dikutip oleh M.Rianto al-Arif, mengatakan "tidak ada batasan tertentu tentang murah dan mahal yang dapat dipatikanhal tersebut ada yang mengaturnya. Prinsipnya tidak bisa diketahui. Murah karena melimpahnya makanan, demikian juga mahal bukan karena kelangkaan makanan. Kadang-kadang makanan sangat sedikit, tetapi harganya murah." Pernyataan ini menyatakan bahwa harga tidak hanya ditentukanoleh penawaran, tetapi juga permintaan terhadap barang tersebut.

Ghafur Abd. (2019) . Mekanisme Pasar Perspektif Islam.Jurn Iqtishodiyah.5(1) :11-15 


\section{Evolusi Pasar Menurut al-Ghazali (1058-1111 M)}

Al-Ihya 'Ulumuddin karya al-Ghazali juga membahas topik-topi ekonomi termasuk pasar. Dalam magnum opus-nya ia membicarakan barter dan permasalahannya, pentingnya aktifitas perdagangan dan evolusi terjadinya pasar, termasuk bekerjanya kekutan permintaan dan penawaran dalam memengaruhi harga.

Dalam terbentuknya pasar menurut al-Ghazali dikutip M.Rianto al-Arif, adalah: "Dapat saja petani hidup ketika alat-alat pertanian tidak tersedia. Sebaliknya, pandai besi dan tukang kayu hidup, tempat lahan pertanian tidak ada. Akan tetapi secara alami mereka akan saling memenuhi kebutuhan masing-masing. Dapat saja terjadi tukang kayu membutuhkan makanan, tetapi petani tidak membutuhkan alatalat tersebut. Keadaan ini menimbulkan masalah. Oleh karena itu, secara alami pula, orang akan terdorong untuk menyediakan tempat penyimpanan alat-alat di satu pihak, dan penyimpanan hasil pertanian dipihak lain. Tempat inilah yang kemudian didatangi pembeli sesuai kebutuhannya masing-masing sehingga terbentuklah pasar. Petani, tukang kayu dan pandai besi yang tidak dapat lengsung melakukan barter juga terdorong pergi kepasar ini. Bila dipasar juga tidak ditemukan orang yang mau melakukan barter, maka ia akan menjual kepada pedagang dengan harga yang relatif murah, untuk kemudian disimpan sebagai persediaan. Pedagang kemudian menjualnya dengan suatu tingkat keuntungan." Hal ini berlaku untuk setiap jenis barang. 
Dari pernyataan tersebut, al-Ghazali menyadari kesulitan yang timbul akibat sistem akibat sistem barter yang dalam istilah ekonomi modern disebut double coincidence, dan karena itu diperlukan suatu pasar. Selanjutnya, ia juga ${ }^{6}$ memperkirakan kejadian ini akan berlanjut dalam skala yang lebih luas. Mencakup banyak daerah atau negara.

Al-Ghazali tidak menolak kenyataan bahwa mencari keuntungan merupakan motif utama dalam perdagangan. Meskipun demikian, ia memberikan banyak penekanan pada etika dalam bisnis, ketika etika ini diturunkan dari nilai-nilai Islam. Keuntungan yang sesungguhnya merupakan keuntungan yang akan diperoleh di akhirat kelak. Ia juga menyarankan adanya peran pemerintah dalam menjaga keamanan jalur perdagangan demi kelancaran perdagangan dan pertumbuhan ekonomi.

\section{Pasar Menurut Pemikiran Ibnu Taimiya}

Pemikiran Ibnu Taimiyah mengenai mekanisme pasar dicurahkan melalui bukunya yang sangat terkenal, yaitu al-Hisbah fi'l al-Islam dan Majmu' fatawa. Pandangan Ibnu Taimiyah menganai hal ini sebenarnya berfokus pada masalah pergerakan harga yang terjadi pada waktu itu, tetapi ia letakkan dalam kerangka mekanisme pasar. Secara umum ia menunjukkan the beauty of market (keindahan mekanisme pasar sebagai meknisme ekonomi), di samping segala kelemahannya. Ibnu Taimiyah berpendapat bahwa kenaikan harga tidak selalu disebabkan oleh ketidak adilan dari para pedangang dan penjual. Sebagaimana banyak dipahami orang

Ghafur Abd. (2019) . Mekanisme Pasar Perspektif Islam.Jurn Iqtishodiyah.5(1) :11-15

Ghafur Abd. (2019) . Mekanisme Pasar Perspektif Islam.Jurn Iqtishodiyah.5(1) :11-15 
pada waktu itu. Ia menunjukkan bahwa harga merupakan hasil interaksi hukum permintaan penawaran yang berbentuk karena berbagai faktor yang kompleks.

Dalam kitab Fatawa-nya Ibnu Taimiyah juga memberikan penjelasan yang lebih terperinci tentang beberapa faktor yang memengarui permintaan, dan kemudian ditingkat harga. Beberapa faktor tersebut menurut Ibnu Taimiyah yang dikutip oleh M.Rianto al-Arif adalah sebagai berikut:

a. Keinginan orang (al-raghabah) terhadap barang sering berbeda-beda.Perbedaan ini dipengaruhi oleh berlimpah atau langkanya barang diminta tersebut (al-matlub). Suatu barang akan lebih sukai apabilania langka daripada tersedia dalam jumlah yang berlebihan.

b. Jumlah orang yang meminta (demend/tullab) juga memengaruhi barang-barang, selain besar dan kecilnya permintaan. Jika kebutuhan terhadap suatu barang kuat dan berjumlah besar, harha akan naik lebih tinggi dibandingkan dengan kebutuhan lemah dan sedikit.

c. Harga juga akan dipengaruhi oleh kuat atau lemahnya kebutuhan terhadap barangbarang, selain besar dan kecilnya permintaan. Jika kebutuhan terhadap suatu barang kuat dan berjumlah besar, harha akan naik lebih tinggi dibandingkan dengan kebutuhan lemah dan sedikit.

d. Harga juga akan bervariasi menurut kualitas pembeli barang tersebut (al-mu'awid). Jika pembeli merupakan orang kaya dan terpecaya (kredibel) dalam membayar kewajibannya, ia akan memperoleh tingkah harga yang lebih rendah dibandingkan dengan orang yang tidak kredibel (suka menunda kewajiban atau mengingkari).

e. Tingkat harga juga dipengaruhi oleh jenis (uang) pembayaran yang digunakan dalam transaksi jual beli. Jika uang yang digunakan adalah uang yang diterima luas, 
kemungkinan harga akan lebih rendah jika dibandingkan dengan menggunakan uang yang kurang luas yang diterima. ${ }^{7}$

f. Tujuan dari suatun trasnsaksi harus menguntungkan penjual dan pembeli. Jika pembeli memiliki kemampuan untuk membayar dan dapat memenuhi semua janjinya, transaksi akan lebih lancar dibandingkan dengan pembeli yang tidak memiliki kemapuan membayar dan mengingkari janjinya. Tingkat harga barang yang yang lebeh nyata (secara fisik) akan lebih rendah dibandingkan dengan yang tidak nyata.

g. Kasus yang sama dapat diterapkan kepada orang yang menyewakan suatu barang. Kemungkinan ia berada pada posisi sedemikian rupa sehingga penyewa dapat memperoleh manafaat dengan tampa (tambahan) biaya apapun. Walaupun demikian, kadang-kadang penyewa tidak dapat memperoleh manfaat ini jika tampa tambahan biaya.

\section{Mekanisme Pasar Menurut Pemikiran Ibnu Khaldun (1332-1406 M)}

Pemikran Ibnu Khaldun tentang pasar termuat dalam buku alMuqaddimah.menurut Ibnu Khaldun dikutip M. Rianto al-Arif mengataka, Ia membagi barang-barang menjadi dua katagori, yaitu barang pokok dan barang barang mewah. Menurutnya, jika suata kota berkembang dan jumlah penduduknya semakin banyak, harga barang-branga pokok akan menurun, sedangkan harga barang mewah akan menaik. Hal ini disebabkan oleh meningkatnya penawaran bahan pangann dan batang pokok lainnya sebab barang ini sangat penting dan dibutuhkan oleh setiap orang sehinga pengadaannya akan diperioritaskan. Adapan harga barang mewah akan

Ghafur Abd. (2019) . Mekanisme Pasar Perspektif Islam.Jurn Iqtishodiyah.5(1) :11-15

Ghafur Abd. (2019) . Mekanisme Pasar Perspektif Islam.Jurn Iqtishodiyah.5(1) :11-15 
naik sejalan dengan meningkatnya gaya hidup yang mengakibatkan penignkatan permintaan barang mewah.

Ibnu Khaldun dikutip M. Rianto al-Arif, juga menjelaskan pengaruh permintaan dan penawaran terhadap tingkat harga. Secara lebih rinci ia menjelaskan pengaruh persaingan diantara para konsumen dannmeningkatnya biaya-biaya akibat perpajakan dan pungutan lain terhadap tingkat harga.

Ibnu Khaldun sangat menghargai garga yang terjadi dalam pasar bebas, tetapi ia tidak mengajukan saran-saran kebijakan pemerintah untuk mengelola harga . ia lebih banyak mefokuskan pada faktor-faktor yang mempengaruhi harga. Hal ini berbeda dengan Ibnu Taimiyah, yang dengan tegas menentang intervensi pemerintah selama pasar berjalan bebas dan normal.

\section{C.PERANAN PEMERINTAH DALAM MENGAWASI PASAR}

Peranan pemerintah sangat penting untuk lebih menjamin berjalannya mekanisme pasar secara sempurna. Rasulullah SAW sendiri telah menjalankan fungsi sebagai pengawas pasar atau al-Hisbah, yang kemudian banyak dijadikan acuan untuk peran negara terhadap pasar. Sementara dalam kitabnya al-Hisbah fi al-Islam, Ibnu Taimiyah banyak mengungkap tentang peranan al-Hisbah pada masa Rasulullah SAW. Rasulullah SAW sering melakukan inspeksi ke pasar untuk mengecek harga dan mekanisme pasar (Al Arif dan Amalia, 2014) . Seringkali dalam inspeksinya, beliau banyak menemukan praktik bisnis yang tidak jujur sehingga beliau menegurnya. Rasulullah SAW juga banyak memberikan pendapat, perintah maupun larangan demi terciptanya pasar yang Islami. Semua ini mengindikasikan dengan 
jelas bahwa al-Hisbah telah ada sejak masa Rasulullah SAW, meskipun nama al-Hisbah baru datang di masa kemudian ${ }^{8}$

Al-Hisbah adalah lembaga yang berfungsi untuk memerintahkan kebaikan sehingga menjadi kebiasaan dan melarang hal yang buruk ketika hal itu telah menjadi kebiasaan umum. Sementara, tujuan al-Hisbah menurut Ibnu Taimiyah adalah untuk memerintahkan apa yang disebut sebagai kebaikan dan mencegah apa yang secara umum disebut sebagai keburukan di dalam wilayah yang menjadi kewenangan pemerintah untuk mengaturnya, mengadili dalam wilayah umum khusus lainnya, yang tak bisa dijangkau oleh institusi biasa. Al-Hisbah tetap banyak didirikan sepanjang bagian terbesar dunia Islam, bahkan di beberapa negara institusi ini tetap bertahan hingga awal abad ke-20 M. Selama periode Dinasti Mamluk, al-Hisbah memiliki peranan penting, terbukti dengan sejumlah kemajuan ekonomi yang dicapai pada masa itu. Di Mesir, al-Hisbah tetap bertahan sampai masa pemerintahan Muhammad Ali (1805-1849 M). Bahkan institusi ini masih banyak dijumpai di Maroko hingga awal abad ke-20 M. Di Romawi Timur, yang telah melakukan kontak dengan dunia Islam melalui Perang Salib, lembaga serupa juga telah diadopsi. Adopsi lembaga ini tampak

${ }^{8}$ Ghafur Abd. (2019) . Mekanisme Pasar Perspektif Islam.Jurn Iqtishodiyah.5(1) :11-15

Hakim M. Arif.(2015). Peran Pemerintah dalam Mengawasi Mekanisme Pasar dalam Perspektif Islam.Jurnal Iqtishodiyah. 8(1):33-38 
jelas dengan nama yang mirip, yaitu Mathessep, yang kemungkinan berasal dari kata Muhtasib.

Pada pemikiran ekonomi Islam kontemporer, eksistensi al-Hisbah seringkali dijadikan acuan bagi fungsi negara terhadap perekonomian, khususnya dalam pasar. Namun, elaborasi al-Hisbah dalam kebijakan praktis ternyata terdapat berbagai bentuk. Beberapa ekonom berpendapat bahwa al-Hisbah akan diperankan oleh negara secara umum melalui berbagai

institusinya. Jadi, al-Hisbah melekat pada fungsi negara dalam pasar dan tidak perlu membentuk lembaga khusus. Sementara itu, sebagian lainnya berpendapat perlunya dibentuk secara khusus lembaga yang bernama al-Hisbah ini. Jadi, al-Hisbah adalah semacam polisi khusus ekonomi. Bahkan lembaga ini merupakan suatu agen independen sehingga terlepas dari kepentingan kelompok tertentu atau pemerintah itu sendiri. Namun, dengan melihat fungsi al-Hisbah yang luas dan strategis ini, adanya suatu agen independen, tampak al-Hisbah akan melekat pada fungsi pemerintah secara keseluruhan, di mana dalam teknis operasionalnya akan dijalankan oleh kementerian, departemen, dinas atau lembaga lain yang terkait.

Pada dasarnya peranan pemerintah dalam perekonomian yang Islami (Misanam dkk., 2008), memiliki dasar rasionalitas yang kokoh. Dalam pandangan Islam, peran pemerintah didasari oleh beberapa argumentasi, yaitu:

1. Derivasi dari konsep kekhalifahan

2.Konsekuensi adanya kewajiban-kewajiban kolektif ( fard al-kifayah), serta

3.Adanya kegagalan pasar dalam merealisasikan falah.

Pemerintah adalah pemegang amanah Allah untuk menjalankan tugas-tugas kolektif dalam mewujudkan kesejahteraan dan keadilan serta tata kehidupan yang baik bagi seluruh umat. Jadi, pemerintah adalah agen dari Tuhan, atau khalifatullah, untuk merealisasikan falah. Sebagai pemegang amanah Tuhan, eksistensi dan peran pemerintah ini memiliki 
landasan kokoh dalam al-Qur'an dan Sunnah, baik secara eksplisit maupun implisit. Kehidupan Rasulullah SAW dan Khulafaur Rasyidin merupakan teladan yang sangat baik bagi eksistensi pemerintah. ${ }^{9}$

Dasar dalam menjalankan amanah tersebut pemerintah akan menjunjung tinggi prinsip musyawarah (syura) sebagai salah satu mekanisme pengambilan ${ }^{10}$ keputusan yang penting dalam Islam. Dengan demikian, pemerintah pada dasarnya sekaligus memegang amanah dari masyarakat.

Peran pemerintah dalam pasar ini secara garis besar dapat diklasifikasikan menjadi dua bagian, yaitu: pertama, peran yang berkaitan dengan implementasi nilai dan moral Islam; kedua, peran yang berkaitan dengan teknis operasional mekanisme pasar.

Beberapa contoh peran pemerintah yang berkaitan dengan implementasi moralitas Islam adalah sebagai berikut (Misanam dkk., 2008):

1. Memastikan dan menjaga implementasi nilai dan moral Islam secara keseluruhan.

Hakim M. Arif.(2015). Peran Pemerintah dalam Mengawasi Mekanisme Pasar dalam Perspektif Islam.Jurnal Iqtishodiyah. 8(1):33-38

Hakim M. Arif.(2015). Peran Pemerintah dalam Mengawasi Mekanisme Pasar dalam Perspektif Islam.Jurnal Iqtishodiyah. 8(1) 33-38 
2. Memastikan dan menjaga agar pasar hanya memperjual-belikan barang dan jasa yang halalan thayyiban. Baang yang haram dan makruh beserta mata rantai produksi, distribusi dan konsumsinya harus dilarang secara tegas.

3. Melembagakan nilai-nilai persaingan yang sehat (. fair play), kejujuran, keterbukaan, dan keadilan. Dalam konteks ini, pemerintah juga harus menjadi al-muhtasib yang memiliki wewenang luas dalam mencegah dan menyelesaikan kasus-kasus pelanggaran nilai-nilai ini. Pada masa Rasulullah SAW beliau terjun sendiri ke pasar untuk menjalankan fungsi al-muhtasib ini.

4. Menjaga agar pasar hanya menyediakan barang dan jasa . sesuai dengan prioritas kebutuhan sebagaimana diajarkan dalam syariah Islam dan kepentingan perekonomian nasional. Barang dan jasa untuk kemewahan dan bersenang-senang akan sangat dibatasi bahkan dilarang seandainya terdapat kebutuhan mendesak terhadap barang-barang primer. Untuk itu, pemerintah harus membuat perencanaan pasar yang berbasiskan prioritas kebutuhan dan mengarahkan para pelaku pasar untuk memenuhi perencanaan ini. Pemerintah juga dapat bertindak sebagai pelaku pasar aktif (produsen) untuk menyediakan kebutuhan-kebutuhan sesuai dengan prioritas syariah dan kepentingan nasional.

Sedangkan peran pemerintah yang khusus berkaitan dengan mekanisme pasar adalah sebagai berikut (Misanam dkk., 2008):

- Secara umum memastikan dan menjaga agar mekanisme . pasar dapat bersaing dengan sempurna. Pemerintah harus menjamin kebebasan masuk dan keluar pasar, menghilangkan berbagai hambatan dalam persaingan seperti monopoli, menyediakan informasi, membongkar penimbunan, melarang kartel-kartel yang merugikan dan lain-lain. 
- Membuat berbagai langkah untuk meningkatkan daya saing . dan daya beli dari para pelaku pasar yang lemah, misalnya produsen kecil dan konsumen miskin.

11

Termasuk dalam hal ini menciptakan berbagai skenario kerja sama di antara para pelaku pasar, misalnya antara produsen besar dengan kecil, untuk meningkatkan efisiensi dan pemerataan.

- Mengambil berbagai kebijakan untuk menciptakan harga. yang adil, terutama seandainya persaingan yang sempurna tidak dimungkinkan terjadi pada pasar. Monopoli tidak selalu akan berdampak buruk bagi masyarakat seandainya harga yang dihasilkan tetap merupakan harga yang adil.

Dalam menjalankan perannya, pemerintah mempunyai beberapa instrumen kebijakan, antara lain sebagai berikut (Misanam dkk., 2008):

- Manajemen produksi dan ketenagakerjaan di sektor publik. Pemerintah dapat berperan efektif dalam mengelola kekayaan publik.

Hakim M. Arif.(2015). Peran Pemerintah dalam Mengawasi Mekanisme Pasar dalam Perspektif Islam.Jurnal Iqtishodiyah. 8(1):19 - 40

Hakim M. Arif.(2015). Peran Pemerintah dalam Mengawasi Mekanisme Pasar dalam Perspektif Islam.Jurnal Iqtishodiyah. 8(1):19 - 40 
Mengatur produksi dan ketenagakerjaan pada sektor ini dapat mempunyai pengaruh besar dalam perekonomian secara keseluruhan.

- Instrumen yang berkaitan dengan upaya mendorong . kegiatan sektor swasta, misalnya menetapkan regulasi bagi sektor swasta, melakukan redistribusi faktor produksi, al-hisbah, perlindungan bagi masyarakat lemah.

- Pricing policy. , di mana negara meregulasi harga dengan cara intervensi pasar, penetapan harga, atau mendorong kebijakan diskriminasi harga untuk kelompok masyarakat daerah, atau sektor tertentu yang dipandang merupakan kepentingan publik. Pricing policy ini juga perlu dilakukan ketika pasar tidak dapat bersaing sempurna sehingga harga yang dihasilkan tidak merugikan masyarakat.

- Kebijakan fiskal, yaitu pengelolaan APBN disesuaikan . dengan prinsip-prinsip keuangan publik Islam.

- Kebijakan pembiayaan dan moneter..

- Investasi kekayaan dan surplus sektor publik. ${ }^{13}$

Hakim M. Arif.(2015). Peran Pemerintah dalam Mengawasi Mekanisme Pasar dalam Perspektif Islam.Jurnal Iqtishodiyah. 8(1):33-38 


\section{BAB III}

\section{PENUTUP}

\section{A.KESIMPULAN}

Pasar yang dibiarkan berjalan sendiri (laissez faire), tanpa ada yang mengontrol, ternyata telah menyebabkan penguasaan pasar sepihak oleh pemilik modal (capitalist) penguasa infrastruktur dan pemilik informasi. Asymetrik informasi juga menjadi permasalahan yang tidak bisa diselesaikan oleh pasar. Negara dalam Islam mempunyai peran yang sama dengan dengan pasar, tugasnya adalah mengatur dan mengawasi ekonomi, memastikan kompetisi di pasar berlangsung dengan sempurna, informasi yang merata dan keadilan ekonomi. Perannya sebagai pengatur tidak lantas menjadikannya dominan, sebab negara, sekali-kali tidak boleh mengganggu pasar yang berjalan seimbang, perannya hanya diperlukan ketika terjadi distorsi dalam sistem pasar.

Konsep makanisme pasar dalam Islam dapat dirujuk kepada hadits Rasululllah SAW. Dengan demikian, Islam jauh mendahului Barat dalam merumuskan konsep mekanisme pasar. Konsep mekanisme pasar dalam Islam selanjutnya dikembangkan secara ilmiah oleh ulama sepanjang sejarah, mulai dari Abu Yusuf, Al-Ghazali, Ibnu Taymiyah, Ibnu Khaldun, dsb. Para ulama tersebut telah membahas konsep mekanisme pasar secara konprehensif. Mereka telah membahas kekuatan supply and demand. Kajian mereka juga telah sampai pada faktar-faktor yang mempengaruhi pasar.

Dalam ekonomi Islam harga ditentukan oleh kekuatan supply and demand. Jika terjadi distorsi pasar maka pemerintah boleh intervensi pasar. Namun, ekonomi 
Islam menentang adanya intervensi pemerintah dengan peraturan yang berlebihan saat kekuatan pasar secara bebas bekerja untuk menentukan harga yang kompetitif. 


\section{DAFTAR PUSTAKA}

Ghafur Abd. (2019) . Mekanisme Pasar Perspektif Islam.Jurn Iqtishodiyah.5(1) :1-19

Hakim M. Arif.(2015). Peran Pemerintah dalam Mengawasi Mekanisme Pasar dalam Perspektif Islam.Jurnal Iqtishodiyah. 8(1):19 - 40

Rahmi Ain.(2015). Mekanisme Pasar dalam Islam. Jurnal Ekonomi Bisnis dan Kewirausahaan.4(2): 177-192 